\title{
Pengaruh Konsentrasi Aktivator Asam Sulfat pada Arang Aktif Kulit Kelapa Muda untuk Menurunkan BOD dan COD
}

\section{Effect of Activator Concentration of Acid Sulphate in Activited Carbon from Young Coconut Fiber to Decrease BOD and COD}

\author{
Sumardiyono $*^{1}$, Dewi Astuti Herawati*2 ${ }^{2}$,an Supriyono \\ Program Studi S1 Teknik Kimia, Fakultas Teknik, Universitas Setia Budi Surakarta \\ *Corresponding author: diyonsumarjo@gmail.com ${ }^{1}$, dewitkusb@gmail.com ${ }^{2}$
}

\begin{abstract}
ABSTRAK
Penelitian ini bertujuan untuk mengetahui konsentrasi aktivator optimum asam sulfat pada arang aktif kulit kelapa muda untuk mendapatkan kapasitas maksimum dalam penurunan angka COD dan BOD limbah cair tahu.

Pembuatan arang aktif kulit kelapa muda dilakukan melalui pemilihan, pencucian, pengeringan, pengarangan, dan aktivasi menggunakan berbagai konsentrasi asam sulfat dengan variabel waktu perendaman. Pengujian BOD dan COD dengan metode titrasi.

Konsentrasi asam sulfat yang dipergunakan $0,5 \mathrm{~N} ; 1 \mathrm{~N} ; 1,5 \mathrm{~N} ; 2 \mathrm{~N}$; dan 2,5 $\mathrm{N}$ dengan waktu perendaman masingmasing konsentrasi 0,5 jam, 1 jam, 1,5 jam, 2 jam dan 2,5 jam.

Hasil percobaan menunjukkan penurunan BOD paling besar pada penyerapan menggunakan arang aktif konsentrasi aktivator asam sulfat 2,5 $\mathrm{N}$ dan waktu perendaman 0,5 jam. Effisiensi penurunan BOD limbah cair tahu sebesar 76,86\% yaitu dari $912 \mathrm{mg} / \mathrm{L}$ menjadi $211 \mathrm{mg} / \mathrm{L}$. Sedangkan penurunan COD limbah cair tahu terbaik dihasilkan saat penyerapan menggunakan arang aktifkonsentrasi aktivator asam sulfat 2,5 N dengan waktu kontak 0,5 jam. Besarnya COD limbah cair tahu terendah $270 \mathrm{mg} / \mathrm{L}$, efisiensi penurunan sebesar 85,60\%. Arang yang telah diaktivasi menggunakan asam sulfat meningkatkan daya penyerapan terhadap angka COD dan angka BOD dibandingkan dengan arang tanpa aktivasi. Peningkatan daya penyerapan masing-masing sebesar $57,76 \%$ dari $27,8 \%$ menjadi $85,56 \%$ dan sebesar 49,54\% dari $27,62 \%$ menjadi $76,86 \%$.
\end{abstract}

Kata kunci: kulit kelapa muda, arang aktif, bod, cod, dan asam sulfat

\section{ABSTRACT}

This study aims to determine the optimum activator concentration of sulfuric acid in young coconut shell activated charcoal to obtain maximum capacity in the decrease of COD and BOD of tofu industrial liquid waste. The activation of the young coconut's charcoal is carried out through selection, washing, drying, bleaching, and activation using various concentrations of sulfuric acid with variable soaking time. Testing of BOD and COD by titration method. Concentration of sulfuric acid used $0.5 \mathrm{~N} ; 1 \mathrm{~N} ; 1.5 \mathrm{~N} ; 2 \mathrm{~N}$; and $2.5 \mathrm{~N}$ with contact time each concentration of 0.5 hours, 1 hour, 1.5 hours, 2 hours and 2.5 hours.

The results showed a large decrease in the BOD on absorption using activated charcoal activator concentration of sulfuric acid $2.5 N$ and the contact time of 0.5 hours.

Effluent BOD removal efficiency out of $76.86 \%$ from $912 \mathrm{mg} / \mathrm{L}$ to $211 \mathrm{mg} / \mathrm{L}$. While the best liquid effluent COD decrease was produced during absorption using activated charcoal concentration of $2.5 \mathrm{~N}$ sulfuric acid activator with 0.5 hour contact time. COD of lowest wastewater of $270 \mathrm{mg} / \mathrm{L}$, efficiency decrease of $85.60 \%$. Charcoal that has been activated using sulfuric acid increases the absorption power of the number of COD and BOD compared with charcoal without activation. The increase of absorption power was $57.76 \%$ from $27.8 \%$ to $85.56 \%$ and $49.54 \%$ from $27.62 \%$ to $76.86 \%$.

Keywords: young coconut fiber, activated carbon, bod,cod, and sulfuric acid

\section{PENDAHULUAN}

Salah satu metode pengolahan limbah cair dapat melalui proses adsorpsi menggunakan arang aktif dari bahan bakar limbah yang mengandung karbon (Sembiring dan Sinaga, 2003). Penggunaan metode ini dikarenakan metode ini relatif sederhana dan efektif (Mukaromah et al., 2016). Pada pengolahan air, arang 
aktif berguna untuk menyisihkan rasa, bau, dan warna (Sembiring dan Sinaga, 2003).

Penelitian mengenai pengolahan limbah cair tahu dan pemanfaatan kulit kelapa muda sebagai adsorben telah banyak dilakukan oleh peneliti-peneliti sebelumnya. Penelitian Ariani, 2015 menghasilkan penurunan BOD dan COD limbah cair industri tahu menggunakan zeolit teraktivasi berturut-turut sebesar 79,75\% dan $82 \%$, zeolit teraktivasi thermal waktu optimum 90 menit dan massa optimum 2 gram. Penelitian tentang penurunan kadar amonia, nitrit, dan nitrat limbah cair industri tahu menggunakan arang aktif ampas kopi juga pernah dilakukan dan dihasilkan penurunan sebesar 64,69\%; $52,35 \%$; dan $86,40 \%$ pada waktu kontak dan $\mathrm{pH}$ optimum (Irmanto, 2009). Adinata (2013) dalam penelitian tentang pemanfaatan limbah kulit kelapa muda sebagai karbon aktif menghasilkan penyerapan terbaik terhadap iodine untuk aktivator $\mathrm{H}_{2} \mathrm{SO}_{4}$ sebesar 45,685\%. Menurut Dika, 2016 penurunan angka BOD, dan COD limbah cair industri tahu sebesar 94,78\%; 94,77\%; menggunakan arang aktif dari kulit pisang dengan waktu kontak 150 menit.

Berdasar penelitian-penelitian yang terdahulu penelitian untuk mengetahui besar penurunan BOD dan COD yang terjadi apabila diolah menggunakan arang aktif dari kulit kelapa muda dengan variasi konsentrasi aktivator $\mathrm{H}_{2} \mathrm{SO}_{4}$, belum pernah dilakukan. Hal inilah yang membedakan penelitian yang akan dilakukan dengan penelitian-penelitian sebelumnya.

\section{METODE PENELITIAN}

\section{Tempat dan Waktu Penelitian}

Penelitian ini dilaksanakan pada semester gasal tahun akademik 2016-2017 di Laboratorium Universitas Setia Budi, Surakarta dan UNS

\section{Alat dan Bahan Penelitian}

Alat yang digunakan adalah bekker glass 1 $\mathrm{L}, \mathrm{pH}$ meter, BOD meter, alat COD, furnace, kompor,oven, cawan porselin, cawan petri, stemper dan mortir, ayakan 80 mesh, desicator, neraca analitik, magnetic stirrer, shaker, sentrifuge, batang pengaduk, dan alat-alat gelas yang umum digunakan dalam laboratorium untuk analisis BOD (Botol BOD, kapasitas 500 $\mathrm{ml}$, inkubator suhu $\pm 20^{\circ} \mathrm{C}$, pipet 25 dan $50 \mathrm{ml}$ ),

Bahan utama yang digunakan dalam penelitian ini adalah sampel limbah cair tahu yang diambil dari pabrik di Krajan RT 03 RW 03, Kelurahan Mojosongo, Kecamatan Jebres, Surakarta, dan kulit kelapa muda yang diperoleh dari pedagang kelapa muda di sekitar Solo

\section{Prosedur Penelitian}

\section{Cara Pengambilan bahan baku limbah cair tahu}

Metode pengambilan sampel pada penelitian ini yaitu dengan metode simple random sampling. Pengambilan sampel sesuai dengan SNI 6989.59:2008, Air dan air limbah-bagian 59 tentang metode pengambilan contoh air limbah.

\section{Pembuatan arang aktif kulit kelapa muda}

Pembuatan arang aktif kulit kelapa muda dilakukan dengan cara, kulit kelapa muda dipotong dengan ukuran $5 \mathrm{~cm}^{2}$, dicuci kemudian dikeringkan dengan sinar matahari selama \pm 7 hari. Selanjutnya kulit kelapa muda tersebut dimasukkan ke dalam furnace dengan suhu $300^{\circ} \mathrm{C}$ selama 0,5 jam. Setelah menjadi arang, dibiarkan dingin dalam desikator. Arang kulit kelapa muda dikeringkan kembali dalam oven pada suhu $105^{\circ} \mathrm{C}$ untuk mengurangi kadar air yang masih terkandung di dalamnya. Kemudian arang kulit kelapa muda dihaluskan dan diayak menggunakan ayakan 80 mesh (Suryani, 2009).

Selanjutnya arang diaktivasi menggunakan larutan $\mathrm{H}_{2} \mathrm{SO}_{4}$ dengan variasi konsentrasi larutan $\mathrm{H}_{2} \mathrm{SO}_{4} 0,5 \mathrm{~N} ; 1,0 \mathrm{~N} ; 1,5 \mathrm{~N} ; 2 \mathrm{~N}$ dan 2,5 N. Kemudian diaduk selama 2 menit direndam masing-masing konsentrasi dengan variabel waktu 0,5 jam, 1 jam, 1,5 jam, 2 jam dan 2,5 jam. Dicuci dengan akuades hingga netral, setelah 
disaring lalu dipanaskan kembali dalam oven pada suhu $105^{\circ} \mathrm{C}$. Setelah itu, didinginkan dalam desikator, ditimbang dan dikeringkan berulang kali hingga diperoleh berat konstan (Wattimury, 2012).

Sebanyak 10 gram arang aktif dengan berbagai hasil aktivasi dicampur dengan $200 \mathrm{ml} \mathrm{lim-}$ bah cair tahu. Campuran tersebut distirer kecepatan 100 rpm selama 2 menit, disaring dan limbah cair tahu yang terpisah dianalisis kadar BOD dan COD.

\section{HASIL DAN PEMBAHASAN Pembuatan Arang aktif}

Hasil penelitian yang meliputi kajian tentang pembuatan arang aktif dari kulit kelapa muda sebagai adsorben guna menurunkan kadar BOD dan COD pada limbah cair tahu. Variabel dalam penelitian ini adalah konsentrasi $\mathrm{H}_{2} \mathrm{SO}_{4}$ dan waktu perendaman arang aktif untuk menyerap limbah cair tahu.

Limbah cair industri tahu diperoleh dari sentra industri kecil tahu dan tempe di desa Krajan, Kelurahan Mojosongo, Kecamatan Jebres, Surakarta. Limbah cair tersebut mempunyai karakteristik sebelum pengolahan yaitu angka BOD 901 mg/L; angka COD 1870 mg/L. Angka BOD dan COD yang melampai batas menurut Perda Propinsi Jawa Tengah No.5 Tahun 2012, maka perlu diturunkan salah satu upaya dengan mengadsorpsi menggunakan arang aktif.

Proses pembuatan arang aktif kulit kelapa muda diawali dengan karbonisasi menjadi arang. Karbon terbentuk secara baik pada suhu antara $300^{\circ} \mathrm{C}$ selama 0,5 jam dalam furnace.

Pada metode ini, proses aktivasi dilakukan dengan menggunakan asam sulfat sebagai aktivator. Aktivasi arang kulit kelapa muda ini dilakukan dengan merendamnya ke dalam $\mathrm{H}_{2} \mathrm{SO}_{4}$ variasi konsentrasi $0,5 \mathrm{~N} ; 1 \mathrm{~N} ; 1,5 \mathrm{~N} ; 2$ $\mathrm{N}$, dan 2,5 N selama 0,5 jam, 1, jam, 1,5 jam, 2 jam dan 2,5 jam. Arang aktif dipergunakan untuk penurunan angka BOD dan COD pada lim- bah cair tahu.

\section{Penurunan Angka BOD}

Hasil penelitian menunjukkan, arang tanpa aktifasi hanya mampu menurunkan angka BOD dari $912 \mathrm{mg} / \mathrm{L}$ menjadi $660 \mathrm{mg} / \mathrm{L}$ atau 27,63\% dan angka COD dari $1870 \mathrm{mg} / \mathrm{L}$ menjadi 1350 $\mathrm{mg} / \mathrm{L}$ atau 38,51 \%. Hasil penurunan angka BOD maupun COD tersebut jauh lebih kecil dibandingkan dengan arang yang telah diaktifkan menggunakan asam sulfat dengan berbagai konsentrasi. Penurunan angka BOD dan angka COD dapat dilihat pada Tabel 1 dan Tabel 2. Penurunan angka BOD menggunakan arang aktifasi dengan asam sulfat mampu menurunkan tertinggi 76,86\%, sedangkan penurunan angka COD dapat mencapai 85,56 \%. Penurunan angka BOD maupun COD ini dijumpai pada adsorpsi limbah cair tahu dengan arang aktif yang diaktifasi menggunakan asam sulfat konsentrasi 2,5 $\mathrm{N}$ dan direndam selama 0,5 jam.

Hubungan waktu perendaman terhadap penurunan BOD pada berbagai konsentrasi asam sulfat arang aktif kulit kelapa muda dipresentasi pada Gambar 1. Hasil penelitian menunjukkan pada konsentrasi asam sulfat 2,5 $\mathrm{N}$ dengan variasi waktu perendaman 0,5 jam, 1 jam, 1,5 jam, 2 jam, dan 2,5 jam angka BOD berturut-turut $211 \mathrm{mg} / \mathrm{L} ; 313 \mathrm{mg} / \mathrm{L} ; 319 \mathrm{mg} / \mathrm{L}$; $292 \mathrm{mg} / \mathrm{L}$ dan $279 \mathrm{mg} / \mathrm{L}$ yaitu mengalami penurunan BOD berturut-turut sebesar 76,86\%; $65,68 \% ; 65,02 \% ; 67,98 \%$ dan $69,41 \%$.

Hasil tersebut lebih rendah apabila dibandingkan hasil perlakuan dengan konsentrasi $2 \mathrm{~N}$; $1,5 \mathrm{~N} ; 1 \mathrm{~N}$ dan 0,5 N. Besarnya efisiensi penurunan BOD berturut-turut tertinggi setiap konsentrasi adalah 64,91\%; 54,50\% ; 44,74\% ; $46,27 \%$. Semakin meningkatnya konsentrasi asam sulfat untuk mengaktivasi, maka akan semakin besar daya adsorpsi yang terjadi. Daya serap arang aktif semakin kuat bersamaan dengan meningkatnya konsentrasi dari aktivator yang ditambahkan.

Pada aktivasi arang menggunakan aktivator 
Tabel 1. Penurunan Angka BOD Limbah Cair Tahu menggunakan Arang Aktivasi dengan Variasi Konsentrasi Asam sulfat dan Waktu Perendaman

\begin{tabular}{|c|c|c|c|c|}
\hline No & $\begin{array}{l}\text { Konsentrasi } \\
\text { Aktivator } \\
\text { ( N ) }\end{array}$ & $\begin{array}{c}\text { Waktu } \\
\text { Perendaman } \\
\text { (jam) }\end{array}$ & $\begin{array}{l}\text { Angka } \\
\text { BOD } \\
\text { mg/L }\end{array}$ & $\begin{array}{c}\text { Effisiensi } \\
\text { Penurunan } \\
\text { Angka BOD } \\
(\%)\end{array}$ \\
\hline \multirow{4}{*}{1} & \multirow{4}{*}{0,5} & $\begin{array}{c}0,5 \\
1\end{array}$ & $\begin{array}{l}551 \\
544\end{array}$ & $\begin{array}{l}39,58 \\
40,35\end{array}$ \\
\hline & & 1,5 & 538 & 41,01 \\
\hline & & 2 & 531 & 41,78 \\
\hline & & 2,5 & 490 & 46,27 \\
\hline \multirow{5}{*}{2} & \multirow{5}{*}{1} & 0,5 & 524 & 42,54 \\
\hline & & 1 & 517 & 43,31 \\
\hline & & 1,5 & 518 & 43,20 \\
\hline & & 2 & 510 & 44,08 \\
\hline & & 2,5 & 504 & 44,74 \\
\hline \multirow{5}{*}{3} & \multirow{5}{*}{1,5} & 0,5 & 455 & 50,11 \\
\hline & & 1 & 449 & 50,77 \\
\hline & & 1,5 & 442 & 51,54 \\
\hline & & 2 & 435 & 52,30 \\
\hline & & 2,5 & 415 & 54,50 \\
\hline \multirow{5}{*}{4} & \multirow{5}{*}{2} & 0,5 & 327 & 64,14 \\
\hline & & 1 & 320 & 64,91 \\
\hline & & 1,5 & 321 & 64,80 \\
\hline & & 2 & 360 & 60,53 \\
\hline & & 2,5 & 346 & 62,06 \\
\hline \multirow{5}{*}{5} & \multirow{5}{*}{2,5} & 0,5 & 211 & 76,86 \\
\hline & & 1 & 313 & 65,68 \\
\hline & & 1,5 & 319 & 65,02 \\
\hline & & 2 & 292 & 67,98 \\
\hline & & 2,5 & 279 & 69,41 \\
\hline
\end{tabular}

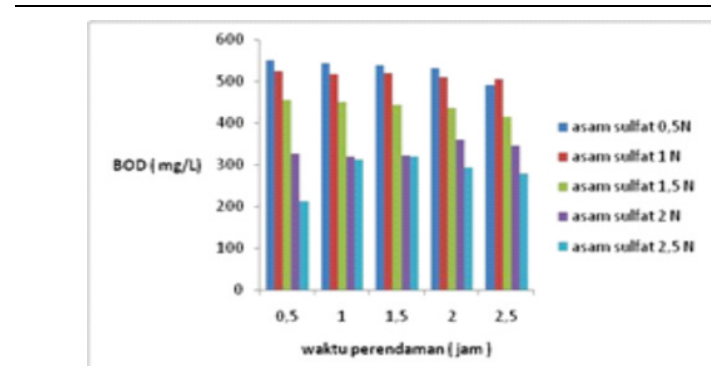

Gambar 1. Hubungan antara waktu perendaman terhadap penurunan BOD pada berbagai konsentrasi asam sulfat arang aktif kulit kelapa muda.

asam sulfat 2,5 $\mathrm{N}$ menunjukkan aktivasi arang yang paling besar daya serapnya. Waktu perendaman yang dibutuhkan hanya 0,5 jam untuk mendapatkan daya serap yang optimal setelah itu daya penyerapan semakin turun. Hal ini disebabkan karena luas permukaan akan terlewat jenuh oleh aktivator sehingga pori-pori tertutup oleh aktivator sehingga luas permukaan untuk adsorbsi kurang optimum.

Hubungan waktu perendaman terhadap penurunan BOD pada berbagai konsentrasi asam sulfat arang aktif kulit kelapa muda dipresentasi pada Gambar 1. Hasil penelitian menunjukkan pada konsentrasi asam sulfat 2,5 N dengan variasi waktu perendaman 0,5 jam, 1 jam, 1,5 jam, 2 jam, dan 2,5 jam angka BOD berturut-turut $211 \mathrm{mg} / \mathrm{L} ; 313 \mathrm{mg} / \mathrm{L} ; 319 \mathrm{mg} / \mathrm{L}$; $292 \mathrm{mg} / \mathrm{L}$ dan $279 \mathrm{mg} / \mathrm{L}$ yaitu mengalami penurunan BOD berturut-turut sebesar 76,86 \%; $65,68 \% ; 65,02 \% ; 67,98 \%$ dan $69,41 \%$.

Penurunan BOD menunjukkan bahwa proses adsorpsi menggunakan karbon aktif telah menyerap bahan organik yang terdapat pada limbah cair industri tahu.

\section{Penurunan Angka COD}

Penurunan COD pada limbah cair industri 
Tabel 2. Penurunan Angka COD Limbah Cair Tahu menggunakan Arang Aktivasi dengan Variasi Konsentrasi Asam sulfat dan Waktu Perendaman

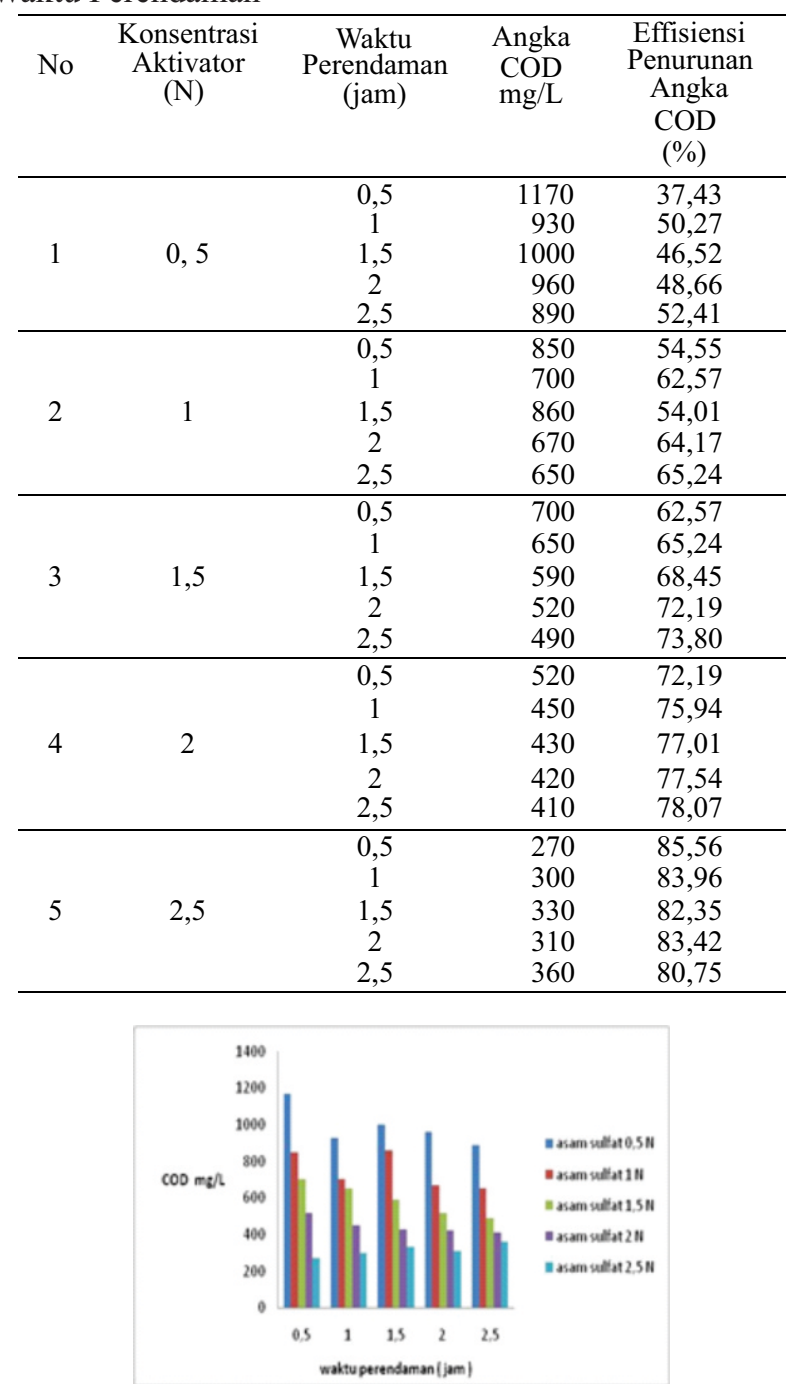

Gambar 2. Hubungan antara waktu perendaman terhadap penurunan COD pada berbagai konsentrasi asam sulfat arang aktif kulit kelapa muda.

tahu setelah dilakukan perendaman beberapa waktu menggunakan berbagai arang diaktifasi dengan berbagai konsentrasi asam sulfat disajikan dalam Gambar 2.

Gambar 2 menunjukkan terjadi penurunan angka COD pada limbah cair industri tahu setelah dilakukan adsorpsi menggunakan arang aktif dengan berbagai konsentrasi asam sulfat dengan waktu perendaman 0,5 jam, 1 jam, 1,5 jam, 2 jam dan 2,5 jam. Masing-masing dengan konsentrasi asam sulfat $0,5 \mathrm{~N} ; 1 \mathrm{~N} ; 1,5 \mathrm{~N} ; 2 \mathrm{~N}$ dan 2,5 $\mathrm{N}$ mengalami penurunan nilai COD dari $2680 \mathrm{mg} / \mathrm{L} ; 2013 \mathrm{mg} / \mathrm{L} ; 1214 \mathrm{mg} / \mathrm{L} ; 875 \mathrm{mg} / 1$ sampai $577 \mathrm{mg} / \mathrm{L}$. Semakin tinggi konsentrasi aktivator, maka akan terjadi penurunan kandungan COD pada limbah cair tahu. Hasil terbaik untuk COD yaitu pada saat diperlakukan dengan konsentrasi aktivator arang aktif 2,5 $\mathrm{N}$ dengan waktu kontak 0,5 jam dan menghasilkan efisiensi sebesar 85,56\%.

\section{KESIMPULAN DAN SARAN}

Dari penelitian yang dilakukan dapat disimpulkan bahwa:

- Semakin besar konsentrasi asam sulfat maka karbon aktif akan semakin baik daya serapnya.

- Hasil terbaik diperoleh pada arang aktif menggunakan aktivator konsentrasi Asam 
Sulfat 2,5 N dan waktu perendaman 0,5 jam mampu menurunkan COD dan BOD limbah cair tahu.

\section{UCAPAN TERIMAKASIH}

Terimakasih kepada Universitas Setia Budi yang telah memberikan dana penelitian melalui Penelitian Terapan tahun 2016.

\section{DAFTAR PUSTAKA}

Ariani, A. T. (2015). Penurunan BOD (Biochemica Oxygen Deman) dan COD (Chemical Oxygen Demen) Pada Limbah Cair Industri Tahu Menggunakan Zeolit Teraktivasi. UIN Sunan Kalijaga Yogyakarta Retrieved from http://digilib.uin-suka.ac.id/15714/

Ariani, W., Sumiyati, S., \& Wardhana, I. W. (2014). Studi Penurunan Kadar COD dan TSS Pada Limbah Cair Rumah Makan Dengan Teknologi Biofilm Anaerob-Aerob Dengan Menggunakan Media Bioring Susunan Random (Studi Kasus: Rumah Makan Bakso Krebo Banyumanik). Jurnal Teknik Lingkungan, 3(1), 1-10.

Darmayanti, D., Rahman, N., \& Supriadi, S. (2012). Adsorbsi Timbal dan Zink Dari Larutannya Menggunakan Arang Kulit Kelapa Muda http://jurnal.untad.ac.id/jurnal/ index.php/JAK/article/view/1493

Dewati, R. (2008). Limbah Kulit Kelapa Muda Sebagai Bahan Pembuat Etanol. UPN "Veteran" Jatim.

Herlambang, A. (2002). Teknologi Pengolahan Limbah Cair Industri. Pusat Pengkajian dan Penerapan Teknologi Lingkungan (BPPT) dan Bapedal. Samarinda.
Irmanto, S. (2009). Penurunan Kadar Amonia, Nitrit, dan Nitrat Limbah Cair Industri Tahu Menggunakan Arang AktifDari Ampas Kopi. Program Studi Kimia, Jurusan MIPAFakultas Sains dan Teknik UNSOED, Purwokerto. Retrieved from http://www.jmolekul.com

Kaswinarni, F. (2007). Kajian Teknis Pengolahan Limbah Padat Dan Cair Industri Tahu Studi Kasus Industri Tahu Tandang Semarang, Sederhana Kendal dan Gagak Sipat Boyolali. Program Pasca Sarjana Universitas Diponegoro. Retrieved from http://eprints.undip.ac.id/17407

Kaswinarni, F. (2013). Kajian Teknis pengolahan limbah padat dan cair industri tahu. Majalah Ilmiah Lontar, 22(2). Retrieved from http://e-jurnal.upgrismg.ac.id/index.php/ LONTAR/article/download/435/391

Nasir, N. S. W., Nurhaeni, N., \& Musafira, M. (2014). Pemanfaatan Arang Aktif Kulit Kelapa Muda Sebagai Absorben Untuk Menurunkan Angka Peroksida Dan Asam Lemak Bebas Minyak Goreng Bekas. Online Journal of Natural Science FMIPA, 3(1). Retrieved from http://jurnal.untad.ac.id/jurnal/index.php/ejurnalfmipa/ar ticle/view/2206

Ratnani, R. D. (2012). Kecepatan Penyerapan Zat Organik Pada Limbah Cair Industri Tahu Dengan Lumpur Aktif. Momentum, 7(2). Retrieved from http://www. unwahas.ac.id/publikasiilmiah/index.php/MOMENTU $\mathrm{M} /$ article/view/100/98

Sembiring, M. T., \& Sinaga, T. S. (2003). Arang Aktif (pengenalan dan proses pembuatannya).

Sherly, A., \& Cahyaningrum, S. E. (2014). Aktivasi Kulit Kelapa Muda Dengan H2SO4 Dan Aplikasi Sebagai Adsorben Ion Logam Cr(VI). UNESA Journal of Chemistry Vol. 3, No 1, January 2014. 